a year and is the principal decision-making organ of the Community. There is also a regional office in Fiji Islands.

Headquarters: BP D5, 98848 Nouméa Cedex, New Caledonia.

Website: http://www.spc.int

e-mail: spc@spc.int

Director-General: Lourdes Pangelinan (Guam).

\title{
PACIFIC ISLANDS FORUM (PIF)
}

In Oct. 2000 the South Pacific Forum changed its name to the Pacific Islands Forum. As the South Pacific Forum it held its first meeting of Heads of Government in New Zealand in 1971. The annual PIF provides an opportunity for discussions to be held on a wide range of issues. The Agreement Establishing the Forum Secretariat defines the membership of the Forum and the Secretariat. Decisions are reached by consensus. The administrative arm of the Forum, known officially as the Pacific Islands Forum Secretariat, is based in Suva, Fiji. In Oct. 1994 the Forum was granted observer status to the UN.

Members. (2003) Australia, Cook Islands, Fiji Islands, Kiribati, Marshall Islands, Micronesia, Nauru, New Zealand, Niue, Palau, Papua New Guinea, Samoa, Solomon Islands, Tonga, Tuvalu and Vanuatu. In 1999 the French territory of New Caledonia was admitted to the Forum as an observer. In 2002 East Timor was admitted to the Forum as a Special Observer.

Functions. The Secretariat's mission is to provide policy options to the Pacific Islands Forum, and to promote Forum decisions and regional and international cooperation. The organization seeks to promote political stability and regional security; enhance the management of economies and the development process; improve trade and investment performance; and efficiently manage the resources of the Secretariat.

Activities. The Secretariat has four core divisions: Trade and Investment; Political and International Affairs; Development and Economic Policy; Corporate Services. The Secretariat provides policy advice to members on a wide range of social, economic and political issues. Since 1989 the Forum has held Post Forum Dialogues with key dialogue partners at ministerial level. There are currently twelve partners: Canada, China, EU, France, India, Indonesia, Japan, South Korea, Malaysia, the Philippines, the United Kingdom and the United States.

Organization. The South Pacific Bureau for Economic Cooperation (SPEC) began as a trade bureau and was established as SPEC in 1972, before being re-organized as the South Pacific Forum Secretariat in 1988. It changed its name to the Pacific Islands Forum Secretariat in 2000. The Secretariat is headed by a Secretary General and Deputy Secretary General who form the Executive. The governing body is the Forum Officials Committee, which acts as an intermediary between the Secretariat and the Forum. The Secretariat operates four Trade Offices in Auckland, Beijing, Sydney and Tokyo.

The Secretary General is the permanent Chair of the Council of Regional Organisations in the Pacific (CROP), which brings together ten main regional organizations in the Pacific region: Fiji School of Medicine (FSM); Forum Fisheries Agency (FFA); Pacific Islands Development Programme (PIDP); Pacific Islands Forum Secretariat (PIFS); Secretariat for the Pacific Community (SPC); South Pacific Applied Geoscience Commission (SOPAC); South Pacific Board for Educational Assessment (SPBEA); South Pacific Regional Environment Programme (SPREP); South Pacific Tourism Organisation (SPTO); and the University of the South Pacific (USP).

Official language: English.

Headquarters: Ratu Sukuna Road, Suva, Fiji Islands.

Website: http://www.forumsec.org.fj

Secretary-General: Gregory Urwin (Australia). 